\title{
Aluminum and benzo[a]pyrene co-operate to induce neuronal apoptosis in vitro
}

\author{
Yin Jinzhu',2, Zhang Qinli², Yang Jin², Kang Pan², Huang Jianjun¹ and Niu Qiao² \\ 'Department of Neurosurgery, Datong Coal Mine General Hospital, 1 Wei Qi Lu, Datong 037003, China \\ ${ }^{2}$ Department of Occupational Health, Institute of Preventive Medicine, Shanxi Medical University, \\ 56 Xin Jian Nan Lu, Taiyuan 030001, China
}

(Received December 7, 2014; Accepted March 14, 2015)

\begin{abstract}
Toxic and harmful factors co-exist in the environment; these factors often interact to induce combined toxicity, which is the main focus of toxicological research. Furthermore, a large number of studies have shown that aluminum $(\mathrm{Al})$ and benzo[a]pyrene $(\mathrm{BaP})$ are neurotoxic and target the central nervous system to cause neuronal apoptosis. Because we are exposed to both $\mathrm{Al}$ and $\mathrm{BaP}$ in the air, water, food, and even medicine, the combined effects of these agents in humans must be examined. The present study examines the ability of $\mathrm{Al}$ and $\mathrm{BaP}$ co-exposure to intensify neuronal apoptosis. The primary neurons of newborn rats were cultured for 5 days, and cells from the same batch that were growing well were selected and assigned to the blank control group, the solvent control group (DMSO+S9+maltol), $\mathrm{BaP}$ groups $(10,40 \mu \mathrm{mol} / \mathrm{L}), \mathrm{Al}(\mathrm{mal})_{3}$ groups $(50,100,400 \mu \mathrm{mol} / \mathrm{L})$ and co-exposure groups with different combinations of $\mathrm{BaP}$ and $\mathrm{Al}(\mathrm{mal})_{3}$. The cell viabilities indicated that $10 \mu \mathrm{M} \mathrm{BaP}$ or $50 \mu \mathrm{M} \mathrm{Al}(\mathrm{mal})_{3}$ was mildly toxic, and we selected $10 \mu \mathrm{M} \mathrm{BaP}+50 \mu \mathrm{M} \mathrm{Al}(\mathrm{mal})_{3}$ for subsequent co-exposure experiments. The morphological characteristics of cell apoptosis were much more obvious in the co-exposure group than in the Al-exposed cells or the BaP-exposed cells, as observed with a transmission electron microscope and a fluorescence inverted microscope. The apoptotic rates and caspase- 3 activity quantitatively significantly differed between the co-exposure and Al-exposure groups, while the BaP-exposure group did not significantly differ from the control group. These results indicate that $\mathrm{Al}$ and $\mathrm{BaP}$ co-exposure exert synergistic effects on neuronal cell apoptosis.
\end{abstract}

Key words: Aluminum, Benzo[a]pyrene, Co-exposure, Neuron, Apoptosis

\section{INTRODUCTION}

Aluminum (Al) is the most abundant metallic element in the earth's crust and is widely used in industrial production and in daily life. It can enter the body via dust, drinking water, foods, cooking utensils, medicine and other avenues. Infant formulae are especially rich in aluminum (Burrell and Exley, 2010). Al concentrations in juice can be as high as $1.8 \mathrm{mM}$ when acidic fruit is boiled in aluminum cookware (Fimreite et al., 1997). Research shows that the exposure level of the general population to $\mathrm{Al}$ is $9-12 \mathrm{mg} / \mathrm{d}$ in China, which is 5 to 9 times higher than that in developed countries (Zhang and Gao, 2003). The permissible concentration-time weighted average (PC-TWA) exposure to $\mathrm{Al}$ is $3 \mathrm{mg} / \mathrm{m}^{3}$ in the workplace in China (GBZ2.1-2007, China). The neurotoxicity of Al has been repeatedly studied and confirmed by many authors in different countries. At the same time, the heavily energy-consuming industrial structure and rapidly increasing number of cars running on the street are emitting high amounts of polycyclic aromatic hydrocarbons (PAHs), which pollute the air and water. Polluted drinking water and foods and polluted air ultimately enter humans via ingestion or inhalation. Benzo[a]pyrene (BaP), a representative substance of PAHs, has already garnered great concern and become an important public health problem in China (Cheng et al., 2014). BaP was identified in fume samples from soybean and peanut oil in China at concentrations of 19.6 and $18.3 \mu \mathrm{g} / \mathrm{m}^{3}$ (Chiang et al., 1997). And the higher BaP level is $0.0303 \mu \mathrm{g} / \mathrm{m}^{3}$, which is three times higher than the national standard in Taiyuan, Shanxi Province. The PAHs deposition flux in rural villages $\left(3.91 \mu \mathrm{g} / \mathrm{m}^{2} /\right.$ day $)$ and urban areas $\left(8.28 \mu \mathrm{g} / \mathrm{m}^{2} /\right.$ day $)$ was 3.8 and 9.1 times higher than that in background areas

Correspondence: Niu Qiao (E-mail: niuqiao55@163.com) 


\section{Y. Jinzhu et al.}

$\left(0.82 \mu \mathrm{g} / \mathrm{m}^{2} /\right.$ day $)$ in the Beijing-Tianjin region of North China (Wang et al., 2011). We are currently exposed to both $\mathrm{Al}$ and $\mathrm{BaP}$ in our living environment. Joint exposure to these two substances is a more serious problem for some occupations, such as aluminum electrolysis workers, who are simultaneously exposed to $\mathrm{Al}$ and $\mathrm{BaP}$, and their exposure level to these pollutants is much higher than that of the general population (Tjoe Ny et al., 1993; Boffetta et al., 1997). Friesen et al. indicated that aluminum smelter workers are exposed to PAHs in many workplaces; even a modest association between aluminum and PAHs produces a high burden (Friesen et al., 2010). Aluminum workers are exposed to coal tar fumes and dusts (contain BaP) during the manufacturing of anodes, which are made from a mixture of coke and coal tar pitch (van Schooten et al., 1995). The involvement of Al in the etiology of Alzheimer's disease is a hot topic and has been debated for many years (Crapper et al., 1973) because Al-induced neurotoxicity causes neuronal loss, A $\beta$ deposition and neurofibrillary tangle-like fibrous structures (Mehta, 2007; Chen et al., 2010). In addition to its carcinogenicity, BaP's toxic effect on the nervous system has aroused concern (He et al., 2012). Scientists noticed that both $\mathrm{Al}$ and $\mathrm{BaP}$ can induce neural cell apoptosis (Zhao et al., 2011; Oshima et al., 2013), which is the basic characteristic of neurodegeneration.

We speculate that $\mathrm{Al}$ and $\mathrm{BaP}$ exert a combined effect on the neural cells to induce apoptosis. The present study mainly observed the aluminum-maltolate and $\mathrm{BaP}$ induced apoptosis in primary neurons of rats, and explored the possible mechanism of the combined effect of $\mathrm{Al}$ and $\mathrm{BaP}$.

\section{MATERIALS AND METHODS}

\section{Preparation of primary cultured cortical neurons (Gartlon et al., 2006)}

The primary neurons of newborn rats were obtained from the cerebral cortices of 0-3-d-old newborn Sprague Dawley rats (provided by the Laboratory of Physiology, Shanxi Medical University) using a method previously described by Gartlon et al. (2006). All animal experiments were approved the institutional Animal Care and Use Committee and were performed in accordance with the Guide for the Care and Use of Laboratory Animals. Briefly, the newborn rats were placed in a $75 \%$ freezing ethanol solution to be anaesthetized. The cerebral cortices were then isolated, and the meninges and white matter were removed. The remaining tissue was dissociated with $0.25 \%$ trypsin (AMRESCO) for $15 \mathrm{~min}$ at $37^{\circ} \mathrm{C}$. Subsequently, the dissociated cortical cells were filtered through a 220-mesh nylon grid, and trypsinization was stopped by adding complete cell medium, which consisted of a DMEM (GIBCO, Grand Island, NY, USA) suspension, $10 \%$ fetal calf serum, and $10 \%$ horse serum (GIBCO) supplemented with 100 units/mL penicillin and $100 \mu \mathrm{g} / \mathrm{mL}$ streptomycin. The density of cells was adjusted to approximately $1 \times 10^{6}$ cells $/ \mathrm{mL}$. The cells were plated in 35-mm tissue culture dishes (GIBCO) coated with poly-D-lysine (Solarbio, Beijing, China) and incubated in a humidified atmosphere containing 5\% $\mathrm{CO}_{2}$ and $95 \%$ air at $37^{\circ} \mathrm{C}$ for $4 \mathrm{hr}$. The cells were then transferred to serumfree culture medium (Neurobasal-A+B27+Glutamine). The serum-free cell culture medium was replaced once every two days.

\section{Preparation of liver post-mitochondrial supernatant (S9) and \$9 mixture}

The liver S9 fraction was a gift from the Shanxi Provincial Center for Disease Control and Prevention. The S9 mixture contained $5 \mathrm{mM}$ glucose-6-phosphate, $4 \mathrm{mM}$ NADP, $8 \mathrm{mM} \mathrm{MgCl}_{2}, 33 \mathrm{mM} \mathrm{KCl}, 100 \mathrm{mM}$ sodium phosphate buffer $(\mathrm{pH}=7.4)$, and $50 \mu \mathrm{L}$ of the $\mathrm{S} 9$ fraction in a total volume of $0.5 \mathrm{~mL}$. This mixture was prepared immediately before each treatment and maintained at $4{ }^{\circ} \mathrm{C}$.

\section{Treatment of cells}

Prior to each experiment, cortical neurons were cultured in triplicate at a density of $1 \times 10^{6}$ cells per dish in 35-mm tissue culture dishes. The cells were assigned to the following groups: blank control, solvent control (DMSO+S9+maltol), mono-exposure, i.e., BaP exposure (10, $40 \mu \mathrm{mol} / \mathrm{L}), \mathrm{Al}(\mathrm{mal})_{3}$ exposure $(50,100,400 \mu \mathrm{mol} / \mathrm{L})$, and co-exposure $\left(10 \mu \mathrm{M} \mathrm{BaP}+50 \mu \mathrm{M} \mathrm{Al}(\mathrm{mal})_{3}, 10 \mu \mathrm{M}\right.$ $\mathrm{BaP}+100 \mu \mathrm{M} \mathrm{Al}\left(\mathrm{mal}_{3}, 10 \mu \mathrm{M} \mathrm{BaP}+400 \mu \mathrm{M} \mathrm{Al} \text { (mal) }\right)_{3}$, $40 \mu \mathrm{M} \mathrm{BaP}+50 \mu \mathrm{M} \mathrm{Al}(\mathrm{mal})_{3}, 40 \mu \mathrm{M} \mathrm{BaP}+100 \mu \mathrm{M} \mathrm{Al}$ $\left.(\mathrm{mal})_{3}, 40 \mu \mathrm{M} \mathrm{BaP}+400 \mu \mathrm{M} \mathrm{Al}(\mathrm{mal})_{3}\right)$. The cells were exposed to the assigned substances for $72 \mathrm{hr}$.

A stock solution of $\mathrm{BaP}$ was dissolved in dimethyl sulfoxide (DMSO) and was maintained at $-20^{\circ} \mathrm{C}$ in the dark; a 3\% S9 mixture was added to the culture medium to obtain the concentrations designated for each treatment. The Al solution was freshly prepared by diluting a $50 \mathrm{mM}$ aluminum-maltolate stock solution in 3-hydroxy2-methyl-4-pyrone (Maltol). The BaP exposure groups were treated with $\mathrm{BaP}$ at a final concentration of 10 or $40 \mu \mathrm{mol} / \mathrm{L}$ in culture medium, and the $\mathrm{Al}$ exposure groups were treated with aluminum-maltolate at a final concentration of 50,100 or $400 \mu \mathrm{mol} / \mathrm{L}$ in culture medium. The co-exposure groups were treated with aluminum-maltolate at a final concentration of 50,100 or $400 \mu \mathrm{mol} / \mathrm{L}$ and $\mathrm{BaP}$ at a final concentration of 10 or $40 \mu \mathrm{mol} / \mathrm{L}$ in 
$\mathrm{Al}$ and $\mathrm{BaP}$ co-operate to induce neuronal apoptosis

culture medium.

\section{Cell viability assay}

The Cell Counting Kit-8 (CCK-8; Dojindo Laboratories, Kumamoto, Japan) produces a highly water-soluble tetrazolium salt, i.e., WST-8[2-(2-methoxy-4-nitrophenyl)-5 -(2,4-disulfophenyl)-2H-tetrazolium, monosodium salt]. In the present study, the Cell Counting Kit- 8 was used to assay cell cytotoxicity as an alternative to the MTT method because the former method is more sensitive.

\section{Acridine orange (AO)-ethidium bromide (EB) double Staining}

To observe the morphology of dead cells, we stained cells with AO-EB. After the treatment period, the cells were washed with PBS; the cells were incubated with AO and $\mathrm{EB}$ at a concentration of $1 \mu \mathrm{g} / \mathrm{mL}$ for $10 \mathrm{~min}$ at room temperature in the dark. The cells were then observed under an inverted research microscope (Olympus IX-71, Tokyo, Japan) using a filter for the $510 \mathrm{~nm}$ wavelength.

\section{Transmission electron microscopy (TEM)}

TEM was performed to determine the ultra-structure of the cells. First, the cells were collected by centrifugation $(1,000 \mathrm{rpm}, 10 \mathrm{~min})$ to form grain-like cell clusters $\left(1 \times 10^{6}\right.$ cells $)$. The cells were then fixed with $3 \%$ glutaraldehyde, followed by $1 \%$ osmium tetroxide. The cells were then suspended in $2 \%$ molten agar and subsequently passed through a series of ethanol dehydration steps. The dehydrated agar blocks were suspended in propylene oxide for $20 \mathrm{~min}$ at $4^{\circ} \mathrm{C}$, followed by treatment with a 1:1 mixture of propylene oxide and araldite for $1 \mathrm{hr}$ at $60^{\circ} \mathrm{C}$. The resin blocks were carefully trimmed to expose the underlying agar blocks. Sections of various thicknesses $(200 \mathrm{~nm}, 300 \mathrm{~nm}$, and $500 \mathrm{~nm})$ were cut using a Leica Ultracut UCT microtome and transferred to 300-mesh copper grids. A 10\% alcohol solution of uranyl acetate was prepared and centrifuged to remove any precipitate. The sections on copper grids were stained for $1 \mathrm{hr}$ with uranyl acetate in the dark at room temperature, washed thoroughly with distilled water, and observed with a Jeol (JEM 2000 FX, Tokyo, Japan) electron microscope at $80 \mathrm{kV}$.

\section{Annexin V-FITC/PI assay}

Apoptosis was detected using an Annexin V-FITC/PI detection kit (Bipec Biopharma Corp., Cambridge, MA, USA) according to the manufacturer's directions. Brief$1 y$, the cells were harvested and re-suspended in buffer $\left(1 \times 10^{6}\right.$ cells $\left./ \mathrm{mL}\right)$. Aliquots of $10^{5}$ cells were mixed with $5 \mu \mathrm{L}$ of Annexin V-FITC and $5 \mu \mathrm{L}$ of PI. After incu- bating the cells for $15 \mathrm{~min}$ at room temperature in the dark, the fluorescence was detected by flow cytometry (Millipore Corporation, Inc., Boston, MA, USA). The percentage of apoptosis was determined from the number of Annexin V(+)/PI(-) cells relative to the number of Annexin $\mathrm{V}(+) / \mathrm{PI}(-)$ cells. The experiment was completed within $1 \mathrm{hr}$ with flow cytometry.

\section{Measurement of activities of caspase- 3}

The activities of caspase- 3 were measured using a caspase-3/CPP32 colorimetric assay kit (BioVision, Inc., Mountain View, CA, USA). Briefly, cultured cortical neurons were lysed using the cell lysis buffer provided in the kit. After determining the protein content, samples containing $50 \mu \mathrm{g}$ of total cell lysate (caspase-3) were assembled in duplicate in 96-well plates with freshly prepared $2 \mathrm{x}$ reaction buffer (containing $10 \mathrm{mM}$ DTT), and the $200 \mu \mathrm{M}$ DEVD-pNA substrate was added to each well. The reaction mixture was incubated at $37^{\circ} \mathrm{C}$ for $2 \mathrm{hr}$. The pNA light emission from the substrate was then quantified using an enzyme-linked immunosorbent assay plate reader at $405 \mathrm{~nm}$.

\section{Statistical analysis}

The data were analyzed using the SPSS11.5 (SPSS Inc., Chicago, IL60606-6412, USA) statistical package and expressed as the mean \pm standard deviation $( \pm$ S.D.). In each phase, a single-factor ANOVA was used to analyze the samples, and a Fisher LSD post hoc test was used when warranted. Additionally, the interaction term of a $2 \times 2$ factorial design $(0 / 10 \mu \mathrm{M}$ BaP and $\left.0 / 50 \mu \mathrm{M} \mathrm{Al}(\mathrm{mal})_{3}\right)$ was used to test for synergism in phase II (Jonker et al., 2004; Elder and Athanasiou, 2008). Significance was defined as $\mathrm{p}<0.05$.

A factorial design analysis of variance was used to analyze the data when a combined effect was studied. If an interaction effect was identified, the type of combined effect was assessed by calculating the separate effect and estimating the marginal means of the data. The marginal means were estimated as follows: if the curves are parallel to each other, it means that there is no interaction. With an increase in the dose, if the curves are far apart, the combined effect can be determined as a synergistic interaction. If the curves are close to each other with the increased dose, the effectis judged to be antagonism.

\section{RESULTS}

\section{Culture conditions of rat neuronal cell}

On the fifth day of cell culture, the cultured cells were observed under an optical microscope (Fig. 1). As the 


\section{Y. Jinzhu et al.}

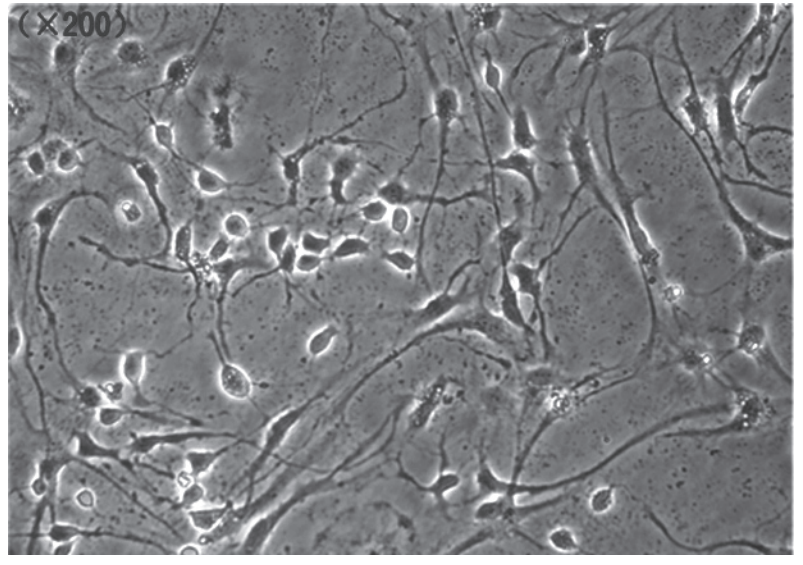

Fig. 1. Primary cultured neurons under an optical microscope (magnification $200 \times$ ). Primary cultured neurons showed membrane integrity, a plump cytoplasm, and many cell junctions, and the synapses were embedded within an elaborate plexus of axons and dendrites.

incubation time was extended, the trunk and branches of the neurites were significantly longer and thicker, the neurite network became denser, and the neuronal cell bodies gradually increased. Neuron-specific class iii $\beta$-tubulin, the protein specifically expressed in neurons, was immunohistochemically stained to ensure that the cultured cells are neurons (Fig. 2).

\section{Cell viability assay}

The cell viabilities of mono-exposure groups $(40 \mu \mathrm{M}$ BaP group; $100 \mu \mathrm{M} \mathrm{Al} \mathrm{(mal)})_{3}$ group, $400 \mu \mathrm{M} \mathrm{Al}($ mal) group) and co-exposure groups $(10 \mu \mathrm{M} \mathrm{BaP}+50 \mu \mathrm{M}$ $\mathrm{Al}$ (mal) ${ }_{3}$ group, $10 \mu \mathrm{M} \mathrm{BaP}+100 \mu \mathrm{M} \mathrm{Al}$ (mal), group, $10 \mu \mathrm{M} \mathrm{BaP}+400 \mu \mathrm{M} \mathrm{Al}(\mathrm{mal})_{3}$ group, $40 \mu \mathrm{M} \mathrm{BaP}+$ $50 \mu \mathrm{M} \mathrm{Al}(\mathrm{mal})_{3}, 40 \mu \mathrm{M} \mathrm{BaP}+100 \mu \mathrm{M} \mathrm{Al}$ (mal), group,

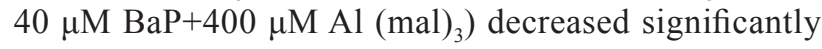
$(\mathrm{P}<0.05)$ compared with the control groups. However, the viabilities of the $10 \mu \mathrm{M}$ BaP group and $50 \mu \mathrm{M} \mathrm{Al}$ $(\mathrm{mal})_{3}$ group only slightly decreased $(\mathrm{P}>0.05)$, indicating that $10 \mu \mathrm{M} \mathrm{BaP}$ or $50 \mu \mathrm{M} \mathrm{Al}$ (mal) $)_{3}$ are only weakly toxic (Table 1). Thus, we selected $10 \mu \mathrm{M} \mathrm{BaP}$ and $50 \mu \mathrm{M} \mathrm{Al}(\mathrm{mal})_{3}$ as "starting doses" to induce apoptosis. We then assessed whether joint exposure to $10 \mu \mathrm{M} \mathrm{BaP}$ and $50 \mu \mathrm{M} \mathrm{Al}$ (mal) ${ }_{3}$ exacerbated this effect.

The cell viability of the $10 \mu \mathrm{M} \mathrm{BaP}+50 \mu \mathrm{M} \mathrm{Al}(\mathrm{mal})_{3}$ group was significantly lower $(\mathrm{P}<0.05)$ than those of the control groups and mono-exposure groups $(10 \mu \mathrm{M} \mathrm{BaP}$, $40 \mu \mathrm{M}$ BaP; $50 \mu \mathrm{M} \mathrm{Al}$ (mal) $)_{3}, 100 \mu \mathrm{M} \mathrm{Al}$ (mal) $)_{3}$ ), suggesting that the combined toxicity of $10 \mu \mathrm{M} \mathrm{BaP}+50 \mu \mathrm{M}$ $\mathrm{Al}$ (mal) ${ }_{3}$ is much greater than mono-exposure to $\mathrm{BaP}$ or

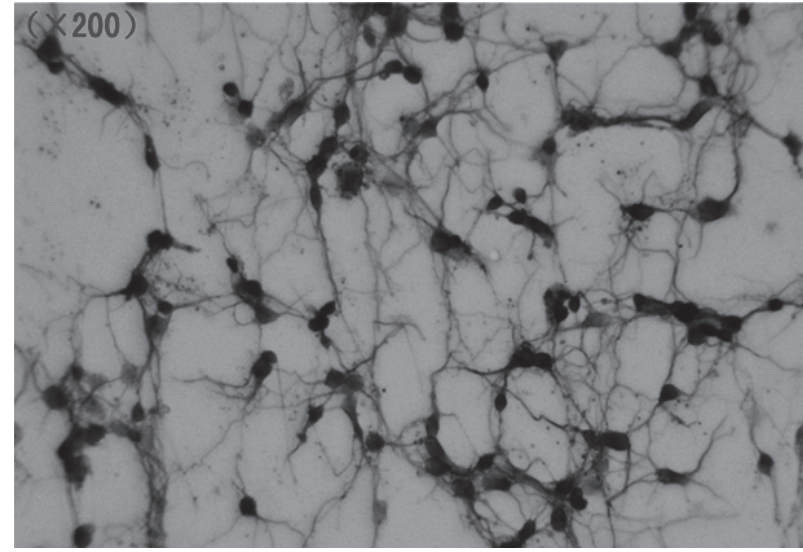

Fig. 2. Primary cultured neurons were immunostained with neuron-specific class iii $\beta$-tubulin (magnification 200 $\times$ ). The cultured cells were immunostained with tubulin-3, which is a specific antigenfor neurons.

$\mathrm{Al}$ (mal) $)_{3}$. Furthermore, increasing the co-exposure dose $\left(10 \mu \mathrm{M} \mathrm{BaP}+400 \mu \mathrm{M} \mathrm{Al}\right.$ (mal) ${ }_{3}$ group, $40 \mu \mathrm{M} \mathrm{BaP}+50 \mu \mathrm{M}$ $\mathrm{Al}$ (mal) ${ }_{3}$ group, $40 \mu \mathrm{M} \mathrm{BaP}+100 \mu \mathrm{M} \mathrm{Al}$ (mal) group, $40 \mu \mathrm{M} \mathrm{BaP}+400 \mu \mathrm{M} \mathrm{Al}\left(\mathrm{mal}_{3}\right)$ significantly decreased the cell viability $(\mathrm{P}<0.05)$, which demonstrates that $\mathrm{BaP}$ and Al co-exposure exerted a significant toxic effect. Overall, $10 \mu \mathrm{M} \mathrm{BaP}+50 \mu \mathrm{M} \mathrm{Al}$ (mal) ${ }_{3}$ co-exposure was significantly more toxic than mono-exposure. Second, the concentrations of aluminum and $\mathrm{BaP}$ are lower in real environments. Thus, the use of $10 \mu \mathrm{M} \mathrm{BaP}+50 \mu \mathrm{M} \mathrm{Al}$ (mal) $)_{3}$ as a co-exposure dose for further studies is realistic and reasonable to mimic the "real exposure" principle of modern toxicological research.

The factorial design analysis of variance shows an interaction between $\mathrm{BaP}$ and $\mathrm{Al}(\mathrm{mal})_{3}(\mathrm{~F}=14.12, \mathrm{P}<0.01)$. The type of combined effect was assessed by estimating the marginal means of the data. The curves diverged as the doses increased, which indicated that these compounds exerted a synergistic effect (Rothman, 1976; Lee et al., 2011) (Fig. 3, Table 1).

\section{Early and late apoptosis detected by AO/EB double staining}

The fluorescence microscopy images obtained from $\mathrm{AO} / \mathrm{EB}$ double staining are shown in Fig. 4. Uniformly green cells with a normal morphology were observed in the control groups, whereas green-stained early apoptotic cells with nuclear margination and chromatin condensation were evident in the BaP-exposure and Al-exposure groups. However, many orange-stained late-stage apop- 


\section{Estimated Marginal Means of Cell Viability}

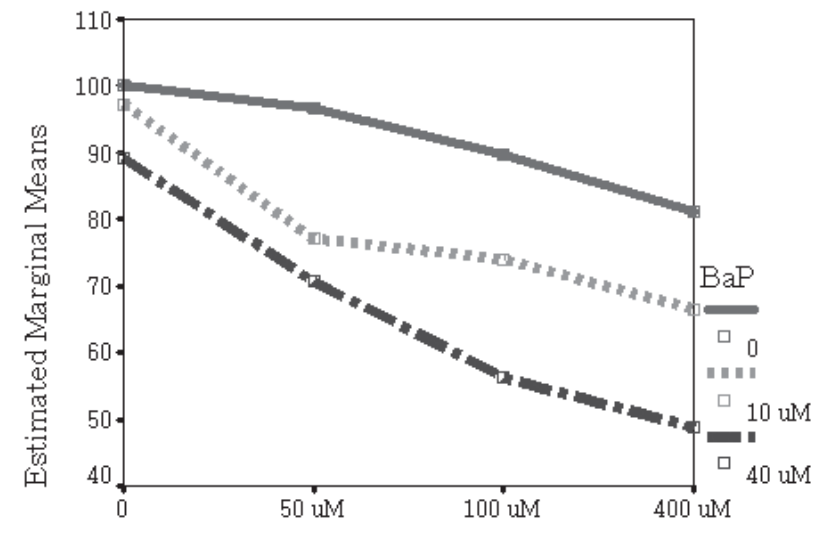

$\mathrm{Al}(\mathrm{mal}) 3$

Fig. 3. Mean interaction diagram of cell viability. The doseeffect curves of BaP-exposure and Al-exposure cells diverged as the dose increased, and the cell viability decreased, which indicated that $\mathrm{BaP}$ and $\mathrm{Al}$ co-exposure exerted a significant synergistic toxic effect. (Each inflection point represents a different experimental group).

totic cells with fragmented chromatin and apoptotic bodies were observed after the co-exposure to $10 \mu \mathrm{M} \mathrm{BaP}+50$ $\mu \mathrm{M} \mathrm{Al}(\mathrm{mal})_{3}$. The results suggest that $\mathrm{Al}$ and $\mathrm{BaP}$ can induce apoptosis in primary cultured neurons and that this effect is exacerbated by the combination of $\mathrm{BaP}$ and $\mathrm{Al}$ (Fig. 4).

\section{Apoptosis morphology observed with transmission electron microscopy}

The electron microscope images showed regular nuclei and evenly distributed chromatin in the control group (A), but those of the $\mathrm{BaP}$-exposure group (B) and $\mathrm{Al}$-exposure group (C) showed nuclear membrane shrinkage, chromatin condensation (e.g., half-moon or strips attached to the nuclear membrane), and slightly swollen mitochondria. The co-exposure group (D) showed an obviously pyknotic nuclear membrane, nuclear fragmentation, mitochondrial swelling and apoptotic bodies (Fig. 5).

\section{Apoptosis rate with Annexin-V/PI double staining}

Flow cytometry was used as described above to quantitatively measure the neuronal apoptosis rate. Compared with the control group, the increase in the apoptosis rate of the BaP-exposure group was not statistically signifi-
Table 1. The cell viability by $\mathrm{BaP}$ and aluminum

\begin{tabular}{|c|c|c|c|}
\hline \multirow{2}{*}{$\frac{\text { Group }}{1 \text { (blank control) }}$} & \multicolumn{2}{|c|}{$\begin{array}{c}\text { Dosage units }(\mu \mathrm{M}) \\
\mathrm{BaP} \mathrm{Al}(\mathrm{mal})_{3}\end{array}$} & \multirow{2}{*}{$\begin{array}{c}\begin{array}{c}\text { Cell viability } \\
\text { (OD value) }\end{array} \\
100^{\#}\end{array}$} \\
\hline & 0 & 0 & \\
\hline 2 (solvent control) & 0 & 0 & $98.84 \pm 0.54^{\#}$ \\
\hline 3 & 10 & 0 & $97.26 \pm 0.56^{\#}$ \\
\hline 4 & 40 & 0 & $89.19 \pm 1.83^{* \#}$ \\
\hline 5 & 0 & 50 & $96.64 \pm 0.90^{\#}$ \\
\hline 6 & 0 & 100 & $89.82 \pm 3.43^{* \#}$ \\
\hline 7 & 0 & 400 & $81.25 \pm 2.42^{*}$ \\
\hline 8 & 10 & 50 & $77.70 \pm 2.53^{*}$ \\
\hline 9 & 10 & 100 & $74.01 \pm 1.09 *$ \\
\hline 10 & 10 & 400 & $66.56 \pm 1.57$ *\# \\
\hline 11 & 40 & 50 & $70.62 \pm 1.57$ *\# \\
\hline 12 & 40 & 100 & $56.23 \pm 2.96^{* \#}$ \\
\hline 13 & 40 & 400 & $48.75 \pm 3.12^{* \#}$ \\
\hline F value & \multicolumn{2}{|c|}{14.12} & $\mathrm{P}<0.01$ \\
\hline $\mathrm{F}(\mathrm{Al})$ value & \multicolumn{2}{|c|}{225.40} & $\mathrm{P}<0.01$ \\
\hline $\mathrm{F}(\mathrm{BaP})$ value & \multicolumn{2}{|c|}{333.01} & $\mathrm{P}<0.01$ \\
\hline
\end{tabular}

Compared with the blank control group, $* \mathrm{P}<0.05$; compared with the group $8,{ }^{\#} \mathrm{P}<0.05$
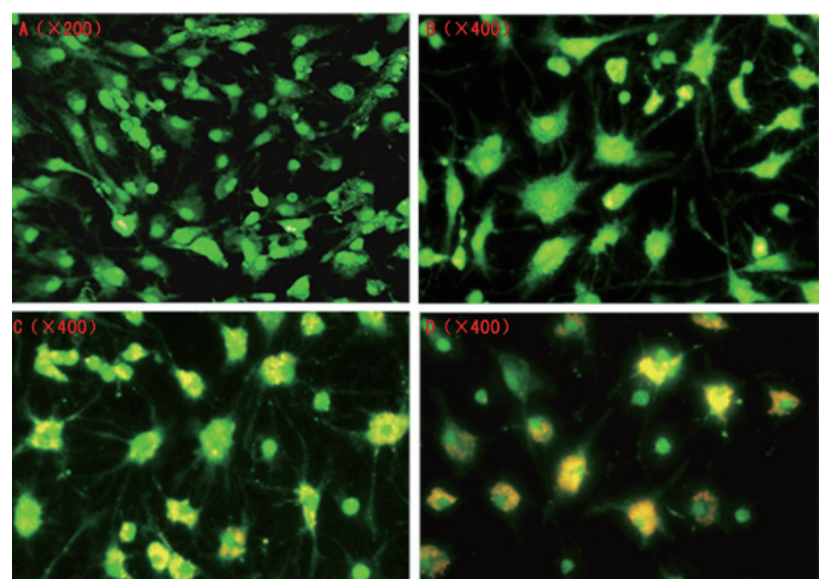

Fig. 4. Primary cultured neurons were stained with AO/EB and observed under a fluorescence microscope (magnification $200 \times / 400 \times$ ). Green-stained live cells showed a normal morphology in the control; green-stained early apoptotic cells showed nuclear margination and chromatin condensation; yellowish orange-stained later apoptotic cells showed fragmented chromatin and apoptotic bodies. All experiments were repeated three times. [Note] A: blank control group; B: $10 \mu \mathrm{M} \mathrm{BaP}$ groups; C: $50 \mu \mathrm{M} \mathrm{Al}$ (mal) ${ }_{3}$ group; D: $10 \mu \mathrm{M} \mathrm{BaP}+50 \mu \mathrm{M} \mathrm{Al}(\mathrm{mal})_{3}$ group. 


\section{Y. Jinzhu et al.}

cant $(\mathrm{P}>0.05)$. However, the increase observed in the Alexposure group was significant $(\mathrm{P}<0.05)$, and that of the co-exposure group was much more significant $(\mathrm{P}<0.01)$ (Fig. 6). The factorial design analysis of variance indicated an interaction effect $(\mathrm{F}=878.65, \mathrm{P}<0.01)$ (Table 2). The type of combined effect was assessed by estimating the marginal means of the data. The curves diverged as the dose increased, which indicated a synergistic interaction.

\section{Measurement of activities of caspase-3}

The caspase- 3 activity was determined in primary cul-
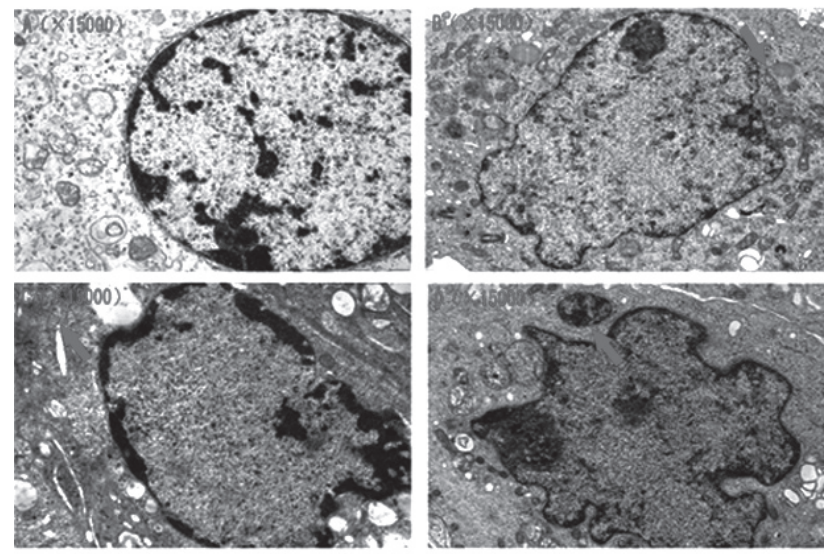

Fig. 5. Apoptosis of primary cultured neurons under a transmission electron microscope (magnification 15,000 $\times$ ). Electron microscopy the confirmed apoptotic characteristics, such as chromatin condensation, mitochondrial swelling, organelle disruption and apoptotic bodies, in $\mathrm{Al}-$ and $\mathrm{BaP}-$ exposure neurons. The arrows indicate the different morphological patterns. Three samples were mixed for each experiment. All experiments were repeated three times. [Note]: (A) blank control group; (B) $10 \mu \mathrm{M}$ BaP groups: arrows show slightly swollen mitochondria; (C) $50 \mu \mathrm{M} \mathrm{Al}$ (mal) ${ }_{3}$ group: arrows shows lightly swollen mitochondria; (D) $10 \mu \mathrm{M} \mathrm{BaP}+$ $50 \mu \mathrm{M} \mathrm{Al}(\mathrm{mal})_{3}$ group: arrows show the formation of apoptotic bodies. tured neurons treated with $10 \mu \mathrm{M} \mathrm{BaP}$ alone, $50 \mu \mathrm{M} \mathrm{Al}$ $(\mathrm{mal})_{3}$ alone and $10 \mu \mathrm{M} \mathrm{BaP}+50 \mu \mathrm{M} \mathrm{Al}$ (mal) $)_{3}$ cultured for $72 \mathrm{hr}$. Compared with the control group, the increase in the caspase- 3 activity in the $10 \mu \mathrm{M}$ BaP-exposure group was not statistically significant $(\mathrm{P}<0.05)$, but the increase in the $50 \mu \mathrm{M}$ Al-exposure group was significant $(\mathrm{P}<0.05)$, and that in the co-exposure group was even more significant $(\mathrm{P}<0.01)$. (Fig. 7)

\section{DISCUSSION}

Humans are often exposed to a combination of $\mathrm{BaP}$ and $\mathrm{Al}$ in their living and occupational environments via various exposure pathways. Neural cells may be highly susceptible to BaP-induced damage (He et al., 2012), and $\mathrm{Al}$ has been considered a neurotoxin that may cause cognitive deficiencies and dementia when it enters the brain (Kawahara, 2005; Kawahara and Kato-Negishi, 2011; Shaw et al., 2014). In addition, the Al concentration is reportedly increased in the brains of AD patients (Andrási et al., 2005; Walton, 2009; Rusina et al., 2011; Bhattacharjee et al., 2013). BaP was reported to induce neurobehavioral deficits in both coking plant workers (Niu et al., 2010) and rats (Nie et al., 2013), and BaP-induced neurotoxicity is involved in the mechanism of neuron apoptosis (Nie et al., 2014). Because both $\mathrm{BaP}$ and $\mathrm{Al}$ are neurotoxic and humans are often co-exposed to both chemicals, these chemicals are likely to synergistically damage the central nervous system to exacerbate human health problems.

Cytotoxic chemicals often induce apoptotic cell death. Apoptosis is one of the main types of programmed cell death and involves a series of biochemical events that lead to specific cell morphology characteristics and ultimately the death of cells. Apoptosis is triggered by multisignal pathways and regulated by complex multi-extrinsic and intrinsic ligands. Mitochondrion-dependent signaling pathways and death receptor-dependent signaling pathways are two major pathways related to apoptosis (Zádor et al., 2003; Liu et al., 2013). In the mitochondrion-de-

Table 2. Neurons apoptosis rate in primary cultured neurons of rat $(\bar{X} \pm$ S.D., $n=3)$.

\begin{tabular}{|c|c|c|c|c|}
\hline \multirow{2}{*}{$\begin{array}{l}\text { Al-exposure } \\
(\mu \mathrm{M})\end{array}$} & \multicolumn{2}{|c|}{ BaP-exposure $(\mu \mathrm{M})$} & \multirow[t]{2}{*}{$\mathrm{F}(\mathrm{BaP})$ value } & \multirow[t]{2}{*}{$\mathrm{P}(\mathrm{BaP})$ value } \\
\hline & 0 & 10 & & \\
\hline 0 & $1.96 \pm 0.07$ & $2.51 \pm 0.15$ & 1085.00 & $<0.001$ \\
\hline 50 & $2.66 \pm 0.34^{*}$ & $13.05 \pm 0.43 * *$ & & \\
\hline F (Al) value & \multicolumn{2}{|c|}{1146.52} & F value & 878.65 \\
\hline P (Al) value & \multicolumn{2}{|c|}{$<0.001$} & $P$ value & $<0.001$ \\
\hline
\end{tabular}

Compared with the blank control group, $* \mathrm{P}<0.05$ and $* * \mathrm{P}<0.01$ 
(a)

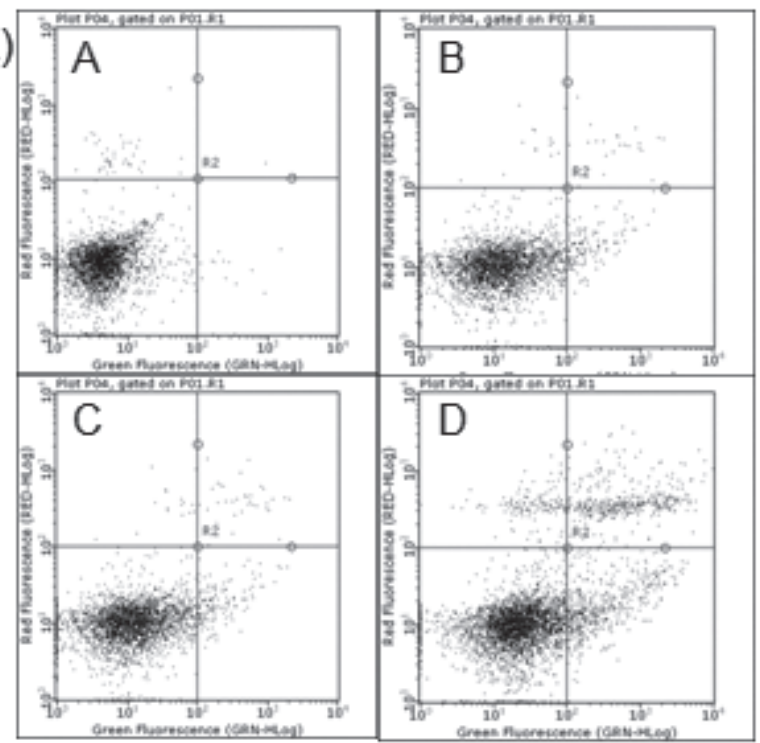

(b)

\section{Estimated Marginal Means of Apoptosis}

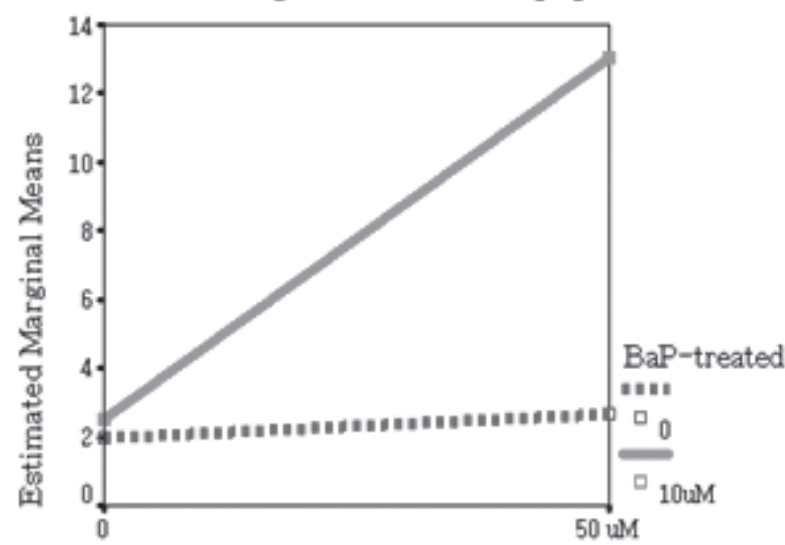

Al-treated

Fig. 6. Neurons apoptosis rate in primary cultured rat neurons. (a) Apoptosis measurement chart of primary cultured rat neurons. Apoptosis was analyzed by AnnexinV-FITC/PI staining $72 \mathrm{hr}$ after treatment. The figures depict representative data. [Note] A: blank control group; B: $10 \mu \mathrm{M} \mathrm{BaP} \mathrm{groups;} \mathrm{C:} 50 \mu \mathrm{M} \mathrm{Al}$ (mal) ${ }_{3}$ group; D: $10 \mu \mathrm{M} \mathrm{BaP}+50 \mu \mathrm{M} \mathrm{Al}$ (mal) ${ }_{3}$ group. (b) Mean interaction diagram of apoptosis rates. The dose-effect curves of $\mathrm{BaP}$-exposure and Al-exposure cells diverged as the dose increased, which indicated that $\mathrm{BaP}$ and $\mathrm{Al}(\mathrm{mal})_{3}$ acted synergistically to induce apoptosis. The impact of both $\mathrm{BaP}$ and Aluminum on neural cell apoptosis is synergistic.

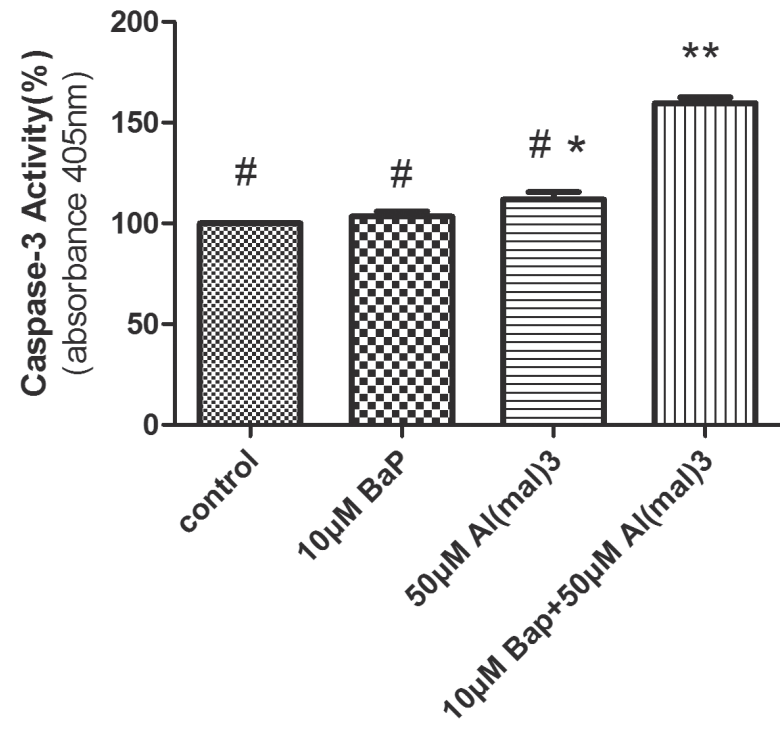

Fig. 7. The activities of caspase-3 in primary cultured rat neurons. [Note]: $* \mathrm{P}<0.05$ versus blank control, $\# \mathrm{P}<0.05$ versus $10 \mu \mathrm{M} \mathrm{BaP}+50 \mu \mathrm{M} \mathrm{Al}(\mathrm{mal})_{3}$ group. pendent signaling pathway, members of the Bcl-2 family may adjust the release of cytochrome $\mathrm{C}$ and the activation of specific proteases (caspase, a proteolytic enzyme that plays a key role in the nuclear fracture and apoptosis), resulting in the inhibition or promotion of apoptosis. This process is known as the "intrinsic pathway" (Stefanis, 2005). The death receptor Fas can specifically bind to Fas ligand (FasL) to induce apoptosis, which is known as the "extrinsic pathway". Both signaling pathways converge at caspase-3, which appears to be the major effector of neuronal apoptosis in response to a variety of stimuli (Sarlak et al., 2013). The activation of caspase-3 then induces the activation of caspase-activated deoxyribonuclease and finally results in cell apoptosis. Neuronal apoptosis is well known to play a key role in the neurodegeneration (Naoi et al., 2012; Jain et al., 2013; Sarlak et al., 2013).

The present experiment focused on $\mathrm{Al}(\mathrm{mal})_{3}$ as the $\mathrm{Al}$ treatment agent. Unlike the vast majority of Al salts, Al $(\mathrm{mal})_{3}$ can form a metastable solution under physiological conditions and release a large number of $\mathrm{Al}^{3+}$ ions. Thus, it offers physiologically realistic aluminum doses in an experimental setting that are useful for Al-related neu- 


\section{Y. Jinzhu et al.}

rotoxicity research (Johnson et al., 2005). $\mathrm{Al}$ (mal) $)_{3}$ can cause primary cultured rat hippocampal neurons apoptosis in neuron aging and in a concentration-dependent manner (Johnson et al., 2005). Neurons are sensitive to low concentrations of Al; 0-2 mmol/L Al can induce neuron apoptosis (Niu et al., 2007). Studies have shown that Al can cause neural cell apoptosis via the mitochondrial pathway and a caspase cascade reaction (Zhang et al., 2005; Kaneko et al., 2007; Niu et al., 2007). BaP is strongly fatsoluble and easily crosses the blood-brain barrier. One of its neurotoxic mechanisms is the induction of neuronal progenitor cell apoptosis via a caspase cascade (Zhao et al., 2011). Kim showed that BaP-induced apoptosis in RL95-2 cells is accompanied by the activation of caspase (Kim et al., 2007). Nie provided direct evidence that BaP induces apoptotic death of cerebral neurons (Nie et al., 2014).

In the present study, the characteristic morphology of apoptosis, such as a pyknotic nuclear membrane and chromatin margination, were observed under an electron microscope. The cells treated with a combination of BaP and Al showed nuclear corpuscles, cracking and even apoptotic bodies, which indicated that the joint effect of the two substances is far greater than their individual effects. Moreover, the AO-EB fluorescence dye staining revealed uniformly green cells and intact connections among the cells in the control group, which indicated live cells. The BaP-exposure group showed a large number of green live cells and a few early apoptotic cells, which contained green or yellow-green bead bodies (apoptotic bodies formed by the fracture of chromatin), and a number of yellow-colored late apoptotic cells appeared in the Alexposure cells. However, apoptosis was more pronounced in the co-exposure group, as evidenced by orange fluorescence dyed bead apoptotic bodies in the plasma, accompanied by nuclear shrinkage and cleavage, or even some necrotic cells, which fluoresced bright red. Moreover, the apoptosis rate significantly increased in the co-exposure group compared with the control group, and a factorial design analysis of variance showed a significant interaction between $\mathrm{BaP}$ and $\mathrm{Al}$ (mal) $)_{3}$, which indicated a synergistic effect. Because the activation of caspase- 3 induces DNA fragmentation, nuclear chromatin condensation, and cell apoptosis (Li et al., 2008), we assessed the caspase-3 activation and found that it significantly increased in the co-exposure group compared with the $\mathrm{Al}$ (mal) ${ }_{3}$ alone or $\mathrm{BaP}$ alone groups, which indicated a synergistic effect. Tu Baijie's study found that $\mathrm{BaP}$ and lead exert synergistic effects; BaP can enhance the neurotoxicity of lead (Tu et $a l ., 2004)$. Both aluminum and lead are neurotoxic metals and are thought to be related to neurodegenerative dis- eases (Weidenhamer et al., 2014); their toxicity mechanisms are similar (Tüzmen et al., 2014). According to the present study, BaP may enhance the neurotoxicity of aluminum, which warrants further study.

In summary, $\mathrm{Al}$ and $\mathrm{BaP}$ exert synergistic effects on neuronal cell apoptosis. However, the specific mechanism of this synergy has not been clarified and requires further research. We will examine these issues in future studies.

\section{ACKNOWLEDGMENTS}

This research work was supported by the National Natural Science Foundation of China (81372698, 81430078).

Conflict of interest---- The authors declare that there is no conflict of interest.

\section{REFERENCES}

Andrási, E., Páli, N., Molnár, Z. and Kösel, S. (2005): Brain aluminum, magnesium and phosphorus contents of control and Alzheimer-diseased patients. J. Alzheimers Dis., 7, 273-284.

Bhattacharjee, S., Zhao, Y., Hill, J.M., Culicchia, F., Kruck, T.P., Percy, M.E., Pogue, A.I., Walton, J.R. and Lukiw, W.J. (2013): Selective accumulation of aluminum in cerebral arteries in Alzheimer's disease (AD). J. Inorg. Biochem., 126, 35-37.

Boffetta, P., Jourenkova, N. and Gustavsson, P. (1997): Cancer risk from occupational and environmental exposure to polycyclic aromatic hydrocarbons. Cancer Causes Control., 8, 444-472.

Burrell, S.A. and Exley, C. (2010): There is (still) too much aluminium in infant formulas. BMC Pediatr, 10, 63.

Chen, T.J., Hung, H.S., Wang, D.C. and Chen, S.S. (2010): The protective effect of Rho-associated kinase inhibitor on aluminuminduced neurotoxicity in rat cortical neurons. Toxicol. Sci., 116, 264-272.

Cheng, J., Song, J., Ding, C., Li, X. and Wang, X. (2014): Ecotoxicity of benzo[a]pyrene assessed by soil microbial indicators. Environ. Toxicol. Chem., 33, 1930-1936.

Chiang, T.A., Wu, P.F., Wang, L.F., Lee, H., Lee, C.H. and Ko, Y.C. (1997): Mutagenicity and polycyclic aromatic hydrocarbon content of fumes from heated cooking oils produced in Taiwan. Mutat. Res., 381, 157-161.

Crapper, D.R., Krishnan, S.S. and Dalton, A.J. (1973): Brain aluminum distribution in Alzheimer's disease and experimental neurofibrillary degeneration. Science, 180, 511-513.

Elder, B.D. and Athanasiou, K.A. (2008): Synergistic and additive effects of hydrostatic pressure and growth factors on tissue formation. PLoS One, 3, e2341.

Fimreite, N., Hansen, O.O. and Pettersen, H.C. (1997): Aluminum concentrations in selected foods prepared in aluminum cookware, and its implications for human health. Bull. Environ. Contam. Toxicol., 58, 1-7.

Friesen, M.C., Demers, P.A., Spinelli, J.J., Eisen, E.A., Lorenzi, M.F. and Le, N.D. (2010): Chronic and acute effects of coal tar pitch exposure and cardiopulmonary mortality among aluminum smelter workers. Am. J. Epidemiol., 172, 790-799.

Gartlon, J., Kinsner, A., Bal-Price, A., Coecke, S. and Clothier, R.H. 
$\mathrm{Al}$ and $\mathrm{BaP}$ co-operate to induce neuronal apoptosis

(2006): Evaluation of a proposed in vitro test strategy using neuronal and non-neuronal cell systems for detecting neurotoxicity. Toxicol In Vitro, 20, 1569-1581.

He, C., Wang, C., Zhou, Y., Li, J. and Zuo, Z. (2012): Embryonic exposure to benzo(a)pyrene influences neural development and function in rockfish (Sebastiscus marmoratus). Neurotoxicology, 33, 758-762.

Jain, V., Baitharu, I., Prasad, D. and Ilavazhagan, G. (2013): Enriched environment prevents hypobaric hypoxia induced memory impairment and neurodegeneration: role of BDNF/ PI3K/GSK $3 \beta$ pathway coupled with CREB activation. PLoS One, 8, e62235.

Johnson, V.J., Kim, S.H. and Sharma, R.P. (2005): Aluminum-maltolate induces apoptosis and necrosis in neuro-2a cells: potential role for p53 signaling. Toxicol. Sci., 83, 329-339.

Jonker, D., Freidig, A.P., Groten, J.P., de Hollander, A.E., Stierum, R.H., Woutersen, R.A. and Feron, V.J. (2004): Safety evaluation of chemical mixtures and combinations of chemical and nonchemical stressors. Rev. Environ. Health, 19, 83-139.

Kaneko, N., Sugioka, T. and Sakurai, H. (2007): Aluminum compounds enhance lipid peroxidation in liposomes: insight into cellular damage caused by oxidative stress. J. Inorg. Biochem., 101, 967-975.

Kawahara, M. (2005): Effects of aluminum on the nervous system and its possible link with neurodegenerative diseases. J. Alzheimers Dis., 8, 171-182; discussion 209-115.

Kawahara, M. and Kato-Negishi, M. (2011): Link between aluminum and the pathogenesis of alzheimer's disease: the integration of the aluminum and amyloid cascade hypotheses. Int. J. Alzheimers Dis., 2011, 276393.

Kim, J.Y., Chung, J.Y., Park, J.E., Lee, S.G., Kim, Y.J., Cha, M.S., Han, M.S., Lee, H.J., Yoo, Y.H. and Kim, J.M. (2007): Benzo[a] pyrene induces apoptosis in RL95-2 human endometrial cancer cells by cytochrome P450 1A1 activation. Endocrinology, 148, 5112-5122.

Lee, Y.S., Han, S.H., Lee, S.H., Kim, Y.G., Park, C.B., Kang, O.H., Keum, J.H., Kim, S.B., Mun, S.H., Shin, D.W. and Kwon, D.Y. (2011): Synergistic effect of tetrandrine and ethidium bromide against methicillin-resistant Staphylococcus aureus (MRSA). J Toxicol. Sci., 36, 645-651.

Li, G., Ma, R., Huang, C., Tang, Q., Fu, Q., Liu, H., Hu, B. and Xiang, J. (2008): Protective effect of erythropoietin on betaamyloid-induced PC12 cell death through antioxidant mechanisms. Neurosci. Lett., 442, 143-147.

Liu, L.W., Lu, J., Wang, X.H., Fu, S.K., Li, Q. and Lin, F.Q. (2013): Neuronal apoptosis in morphine addiction and its molecular mechanism. Int. J. Clin. Exp. Med., 6, 540-545.

Mehta, P.D. (2007): Amyloid beta protein as a marker or risk factor of Alzheimer's disease. Curr. Alzheimer Res., 4, 359-363.

Naoi, M., Maruyama, W. and Inaba-Hasegawa, K. (2012): Type A and $\mathrm{B}$ monoamine oxidase in age-related neurodegenerative disorders: their distinct roles in neuronal death and survival. Curr. Top Med. Chem., 12, 2177-2188.

Nie, J.S., Zhang, H.M., Zhao, J., Liu, H.J. and Niu, Q. (2014): Involvement of mitochondrial pathway in benzo[a]pyrene-induced neuron apoptosis. Hum. Exp. Toxicol., 33, 240-250.

Nie, J.S., Duan, L., Yan, Z.W. and Niu, Q. (2013): Tau hyperphosphorylation is associated with spatial learning and memory after exposure to benzo[a]pyrene in SD rats. Neurotox. Res., 24, 461-471.

Niu, Q., Zhang, Q., Niu, P. and Shi, Y. (2007): Study of neurocytes apoptosis in vitro culture rat induced by aluminum. Wei Sheng Yan Jiu, 36, 407-413.

Niu, Q., Zhang, H., Li, X. and Li, M. (2010): Benzo[a]pyrene-in- duced neurobehavioral function and neurotransmitter alterations in coke oven workers. Occup. Environ. Med., 67, 444-448.

Oshima, E., Ishihara, T., Yokota, O., Nakashima-Yasuda, H., Nagao, S., Ikeda, C., Naohara, J., Terada, S. and Uchitomi, Y. (2013): Accelerated tau aggregation, apoptosis and neurological dysfunction caused by chronic oral administration of aluminum in a mouse model of tauopathies. Brain Pathol., 23, 633-644.

Rothman, K.J. (1976): The estimation of synergy or antagonism. Am. J. Epidemiol., 103, 506-511.

Rusina, R., Matěj, R., Kašparová, L., Kukal, J. and Urban, P. (2011): Higher aluminum concentration in Alzheimer's disease after Box-Cox data transformation. Neurotox. Res., 20, 329-333.

Sarlak, G., Jenwitheesuk, A., Chetsawang, B. and Govitrapong, P. (2013): Effects of melatonin on nervous system aging: neurogenesis and neurodegeneration. J. Pharmacol. Sci., 123, 9-24.

Shaw, C.A., Seneff, S., Kette, S.D., Tomljenovic, L., Oller, J.W.Jr. and Davidson, R.M. (2014): Aluminum-induced entropy in biological systems: implications for neurological disease. J. Toxicol., 2014, 491316.

Stefanis, L. (2005): Caspase-dependent and -independent neuronal death: two distinct pathways to neuronal injury. Neuroscientist, 11, 50-62.

Tjoe Ny, E., Heederik, D., Kromhout, H. and Jongeneelen, F. (1993): The relationship between polycyclic aromatic hydrocarbons in air and in urine of workers in a Söderberg potroom. Am. Ind. Hyg. Assoc. J., 54, 277-284.

Tu, B., Cheng, S. and Hu, X. (2004): Effects on the survival rates and damage on DNA of benzo[a]pyrene or lead alone or in combination in rat neurons in vivo. Wei Sheng Yan Jiu, 33, 660-662.

Tüzmen, M.N., Yücel, N.C., Kalburcu, T. and Demiryas, N. (2014): aluminum- and lead-induced oxidative neurotoxicity and alterations in NMDA receptors. Toxicol. Mech. Methods, 24, 1-8.

van Schooten, F.J., Jongeneelen, F.J., Hillebrand, M.J., van Leeuwen, F.E., de Looff, A.J., Dijkmans, A.P., van Rooij, J.G., den Engelse, L. and Kriek, E. (1995): Polycyclic aromatic hydrocarbon-DNA adducts in white blood cell DNA and 1-hydroxypyrene in the urine from aluminum workers: relation with job category and synergistic effect of smoking. Cancer Epidemiol. Biomarkers Prev., 4, 69-77.

Walton, J.R. (2009): Brain lesions comprised of aluminum-rich cells that lack microtubules may be associated with the cognitive deficit of Alzheimer's disease. Neurotoxicology, 30, 1059-1069.

Wang, W., Massey Simonich, S.L., Giri, B., Xue, M., Zhao, J., Chen, S., Shen, H., Shen, G., Wang, R., Cao, J. and Tao, S. (2011): Spatial distribution and seasonal variation of atmospheric bulk deposition of polycyclic aromatic hydrocarbons in Beijing-Tianjin region, North China. Environ. Pollut., 159, 287-293.

Weidenhamer, J.D., Kobunski, P.A., Kuepouo, G., Corbin, R.W. and Gottesfeld, P. (2014): Lead exposure from aluminum cookware in Cameroon. Sci. Total Environ., 496, 339-347.

Zádor, Z., Lacza, Z., Benyó, Z., Harkány, T. and Hortobágyi, T. (2003): Apoptosis in focal brain ischemia. Ideggyogy Sz, 56, 216-228.

Zhang, L. and Gao, J. (2003): Comparison on intake status of harmful elements between China and some developed countries. Wei Sheng Yan Jiu, 32, 268-271.

Zhang, Q.L., Niu, P.Y., Niu, Q. and Wang, L.P. (2005): Effect of aluminum on neuronal mitochondria of rats. Wei Sheng Yan Jiu, 34, 674-677.

Zhao, J., Wang, L.P., Nie, J.S. and Niu, Q. (2011): Effects of benzo(a)pyrene on apoptosis of neuronal cells and expression of $\mathrm{Bcl}-2$ and Bax proteins in rat brain tissue. Zhonghua Lao Dong Wei Sheng Zhi Ye Bing Za Zhi, 29, 820-824. 